\title{
PENINGKATAN KUALITAS KERJA MELALUI POLA PEMBINAAN (CAPACITY BUILDING) DOSEN MUDA PADA PROGRAM STUDI ADMINISTRASI PENDIDIKAN SPS UPI
}

\author{
H. Djaman Satori, Asep Suryana \\ Dosen Universitas Pendidikan Indonesia \\ djaman@upi.edu
}

\begin{abstract}
ABSTRAK
Ukuran kinerja dosen yang baik ditentukan oleh pencapaian setiap komponen dalam indikator akademik, penelitian dan pengabdian kepada masyarakat. Dalam pelaksanaannya sering ditemukan hal-hal yang memposisikan bahwa distribusi ketiga indikator tersebut tidak memenuhi standar yang ditetukan, apalagi ketika didasarkan kepada ukuran/alat dalam bentuk Beban Kinerja Dosen. Beberapa hal yang ingin diangkat dalam penelitian ini meliputi kemampuan dosen muda dalam pembelajaran, kehadiran dosen muda dalam proses pembelajaran, dan kesiapan dosen muda dalam meneruskan estapet pembinaan mata kuliah. Masalah yang diangkat dalam penelitian ini meliputi hal-hal sebagai berikut:1) Bagaimana kemampuan dosen muda dalam proses pembelajaran di dalam kelas? 2) Bagaimana komitmen dan tanggungjawab dosen muda terhadap tugas pokok dan fungsi sebagai tenaga dosen? 3) Bagaimana pola-pola kadersisasi dilakukan dalam pengembangan keilmuan dan pengembangan profesi? Penelitian ini menggunakan metode kuantitatif kualitatif dengan menggungkan instrumen terbuka, wawancara, dan studi dokumentatif terhadap hasil-hasil kerja dosen. Hasil yang diperoleh meliputi; Pemahaman dan kemampuan dosen muda dalam menerjemahkan tugas dan tanggungjawabnya menjadi ukuran dosen muda untuk memperoleh kesempatan madiri dalam pembelajaran atau masih harus memperoleh bimbingan dari dosen senior/pembina. Dalam bidang akademik dibuktikan dengan proses pembelajaran dan bimbingan yang dilakukan di kelas, penelitian dibuktikan dengan karya ilmiah yang dihasilan, dan pengabdian masyarakat dibuktikan dengan bentuk-bentuk pengembangan yang bermanfaat bagi kehidupan masyarakat, baik masyarakat umum maupun secara khusus masyarakat pendidikan.
\end{abstract}

Kata Kunci: dosen muda, kinerja dosen, tridarma perguruan tinggi, beban kinerja dosen, team teaching, capacity building

\section{ABSTRACT}

The measurement of a well lecture work is decided by achievement from every component in academic indicator of research and community service. Practically, there are found many things that were positioned that distribution those three indicators have not certain criteria, especially when it is based on the measurement / tool in form of a lecturer burden work. There are something that wanted to be appeared in this research such as (1) how is the ability of young lecturer in learning, attendance of young lecturer in learning, and the readiness of young lecturer in continuing the guidance of subject. The problems that are raised in this research include to the things bellows; (1) How is commitment and responsibility of young lecturer in the process of learning in the class, (2) how are the patterns of cadres forming is done in growing the science and profession? This research used the quantitative and qualitative method by using open instrument, interview, and document study to result work of the lecturer. Meanwhile, the result that is obtained are included to comprehending and ability of young lecturer in translating the task and still need the guidance of senior lecturer. In academic area was proven by learning and guiding in the class, moreover the research was proven by a paper and community service was proven by the form the growing of life society generally and specifically in academic area.

Keywords: young lecturer, lecturer work, university tridarma, lecturers'burden work, building capacity

\section{PENDAHULUAN}

Ukuran kinerja dosen yang baik ditentukan oleh pencapaian setiap komponen dalam indikator akademik, penelitian dan pengabdian kepada masyarakat. Akurasi pemenuhan setiap komponen dalam indikator tersebut bergantung kepada pemahaman dan kemampuan dosen dalam menerjemahkan tugas dan tanggungjawabnya dalam pekerjaan sehari-hari. Ketiga indikator tersebut menjadi satu kesatuan tanggungjawab yang tidak bisa dilepaskan pemenuhannya harus menyeluruh. 
Dalam pelaksanaannya sering ditemukan hal-hal yang memposisikan bahwa distribusi ketiga indikator tersebut (tri darma perguruan tinggi) tidak memenuhi standar yang ditentukan, apalagi ketika didasarkan kepada ukuran/alat dalam bentuk Beban Kinerja Dosen. Dosen dapat memenuhinya akan tetapi dilihat dari kualitas masih berada jauh dari standar yang diharapkan atau tidak dapat memenuhinya sama sekali karena tidak terlibat terutama dalam aktivitas penelitian dan pengabdian pada masyarakat.

Dalam penelitian ini, tugas akademik sebagai inti permasalahan yang ingin dilihat. Beberapa hal yang ingin diangkat meliputi kemampuan dosen muda dalam pembelajaran, kehadiran dosen muda dalam proses pembelajaran, dan kesiapan dosen muda dalam meneruskan estapet pembinaan mata kuliah. Sementara ini dosen muda pada Program Studi Administrasi Pendidikan ada kurang lebih 14 orang, dari data terakhir diperoleh bahwa kehadiran di kelas masih membutuhkan pengawasan dari senior atau dosen pembina juga ketua prodi karena masih kurang. Selain kehadiran, mutu proses belajar mengajar dengan pendekatan andragogik perlu terus di-monitoring dan dievaluasi sehingga keluhan-keluhan tentang kualitas menyangkut substansi dan penggunaan metode pembelajaran semakin berkurang dan mutu layanan dapat ditingkatkan.

\section{Kinerja}

Kinerja adalah hasil kerja suatu organisasi dalam rangka mewujudkan tujuan strategik, kepuasan pelanggan dan kontribusinya terhadap lingkungan strategik.Kinerja merupakan hasil kerja keras organisasi dalam mewujudkan tujuan strategik yang ditetapkan organisasi, kepuasan pelanggan serta kontribusinya terhadap perkembangan ekonomi masyarakat". Secara sepintas kinerja dapat diartikan sebagai perilaku berkarya, berpenampilan atau hasil karya. Oleh karena itu, kinerja merupakan bentuk bangunan yang multidimensional, sehingga cara mengukurnya sangat bervariasi tergantung kepada banyak faktor (Bates dan Holton, 1995).

Adapun pengertian kinerja menurut Nanang Fattah (1999:19-21) adalah "ungkapan kemampuan yang didasari oleh pengetahuan, sikap dan keterampilan, dan motivasi dalam menghasilkan sesuatu".

Mengutip pendapat Haerani yang ditulis oleh T. R. Mitchell(2000:199) dalam People InOrganizations Understanding Their Behaviour, mengemukakan bahwa kinerja meliputi aspek-aspek:a) Quality of work, b) Promptness, c) Initiative, d) Capability, e) Communication.

\section{Pembelajaran Model Tim}

Melalui kegiatan pembelajaran tim, wawasan yang didapatkan kemudian diterjemahkan ke dalam tindakan. Keterampilan yang terbentuk dapat menyebar ke individu lain dan ke tim lain (walaupun tidak ada jaminan bahwa mereka akan menyebar). Keberhasilan tim dapat menjadi acuan standar untuk belajar bersama bagi organisasi yang lebih besar (Senge, 1996:236).

MenurutSenge(1996:236) didalam organisasi pembelajaran tim memiliki tiga dimensi yang kritis. Dimensi-dimensi tersebut adalah: (a) Ada kebutuhan untuk berpikir dengan penuh wawasan masalah kompleks. Disini,tim harus belajar menyuling potensi bagi pemikiran dari banyak orang untuk menjadi lebih unggul daripada pemikiran dari satu orang; (b) Ada kebutuhan akan tindakan yang inovatif dan terkoordinasi; dan (c) Peranan dari anggota tim pada tim lainnya.

Kemampuan dialog dan berbagi pengetahuan merupakan disiplin fundamental dari organisasi pembelajaran. Melalui dialog dan berbagi pengetahuan ini, para anggota organisasi mampu memahami bagaimana setiap individu memperoleh pemahaman tentang struktur dan proses kerja dalam organisasi. 
Dalam pelaksanaan pembelajaran tim, dapat dikembangkan metode pembelajaran kolaboratif (Collaborative teaching), seperti dikemukakan oleh Ellisabeth (2002: 4) bahwa: "collaborative learning is the instructional use ofsmall groups. Its goal is to allow student to work together to maximize their own and other's learning. Thetraditional teacher's role is exponded to include facilitating and coordinating the student group, which then assume part of the responsibility for instruction".

Pembelajarankolaboratifyang dikembangkan dalam pelaksanaan di kelas tidak ada perbedaan tugas masing-masing individu dalam kelompok baik dosen senior dengan dosen muda, melainkan tugas tersebut adalah tugas yang menjadi milik bersamauntuk dituntaskan bersama-sama. Dalam proses pembelajaran kolaboratif penekanannya adalah bagaimana menciptakan kerjasama, interaksi, saling berbagi informasi antara dosen senior dengan dosen muda. Pada dasarnya metode pembelajaran kolaboratif menekankan bahwa dalam kelompok pengajar dalam satu kelompok itu memiliki rasa saling ketergantungan dalam pelaksanaan tugas, bekerja bersama, adanya saling tukar informasi, pengetahuan, dan saling berinteraksi satu sama lainnya.

Ada hal pokok yang harus diperhatikan oleh dosen senior dengan dosen muda yang dibina yaitu: (1) berbagi pengetahuan, melalui perubahan pola hubungan, (2) berbagi otoritas, (3) dosen senior berperan sebagai penghubung, dan (4) adanya sharing secara terbuka.

\section{Strategi Pembinaan Dosen Muda}

Pengembangan (development) adalah proses peningkatan keterampilan teknis, teoritis, konseptual, dan moral karyawan melalui pendidikan dan pelatihan. Pendidikan dan pelatihan yang diberikan harus sesuai dengan kebutuhan pekerjaan masa kini maupun masa depan.
Konsep capacity building dapat dimaknai sebagai proses membangun kapasitas individu, kelompok atau organisasi. Capacity building dapat juga diartikan sebagai upaya memperkuat kapasitas individu, kelompok atau organisasi yang dicerminkan melalui pengembangan kemampuan, keterampilan, potensi dan bakat serta penguasaan kompetensi-kompetensi sehingga individu, kelompok atau organisasi dapat bertahan dan mampu mengatasi tantangan perubahan yang terjadi secara cepat dan tak terduga. Capacity building dapat dimaknai sebagai proses kreatif dalam mengembangkan kemampuan yang sudah ada. Capacity building dapat pula dimaknai sebagai proses kreatif dalam membangun kapasitas yang belum nampak.

Brown (2001:25) mendefinisikan capacity building sebagai suatu proses yang dapat meningkatkan kemampuan seseorang, suatu organisasi atau suatu sistem untuk mencapai tujuan-tujuan yang dicita-citakan. Sedangkan Morison (2001:42) melihat capacity building sebagai suatu proses untuk melakukan sesuatu, atau serangkaian gerakan, perubahan multi level di dalam individu, kelompokkelompok, organisasi-organisasi dan sistemsistem dalam rangka untuk memperkuat kemampuan penyesuaian individu dan organisasi sehingga dapat tanggap terhadap perubahan lingkungan yang ada.

Dengan pernyataan di atas, Morison berusaha mendefinisikan capacity building atau pengembangan kapasitas sebagai Actionable Learning. Sebuah proses yang menyebabkan atau menggerakkan perubahan multitingkatan pada individu, grup, organisasi dan sistem. Idealnya, pengembangan kapasitas berupaya memperkuat kemampuan adaptasi diri dan organisasi, dengan tujuan agar mereka dapat merespon perubahan lingkungan dan dalam pernyataan tersebut terdapat kata kunci definitif tentang pengembangan kapasitas, yakni: (a) Pengembangan kapasitas bukanlah produk, melainkan sebuah proses; (b) Pengembangan kapasitas adalah proses 
pembelajaran multi-tingkatan meliputi individu, grup, organisasi dan system; (c) Pengembangan kapasitas menghubungkan ide terhadap sikap; dan (d) Pengembangan kapasitas dapat disebut sebagai actionable learning dimana pengembangan kapasitas meliputisejumlahproses-prosespembelajaran yang saling berkaitan, akumulasi benturan yang menambah prospek untuk individu dan organisasi agar secara terus menerus beradaptasi atas perubahan.

Pengertian lain mengenai capacity building juga dikemukakan oleh Katty Sensions (1993:15) yang memberikan definisi sebagai berikut:"capacity building usually is understood to mean helping governments, communities and individuals to develop the skills and expertise needed to achieve their goals. Capacity building program, often designed to strengthen participant's abilities to evaluate their policy choices and implement decisions effectively, may include education and training, institutional and legal reforms, as well as scientific, technological and financial assistance"

Pengembangan kapasitas bisa meliputi pendidikan dan pelatihan, reformasi peraturan dan kelembagaan, dan juga asistensi finansial, teknologi dan keilmuwan.Dari definisi para ahli di atas, dapat ditarik kesimpulan bahwa capacity building atau pengembangan kapasitas merupakan proses meningkatkan kemampuan, keterampilan, bakat, dan potensi yang dimiliki oleh individu, kelompok individu atau organisasi untuk memperkuat diri sehingga mampu mempertahankan profesinya di tengah perubahan yang terjadi di lingkungan individu, kelompok individu atau organisasi.

\section{METODE PENELITIAN}

Penelitian ini menggunakan metode kuantitatif kualitatif dengan menggunakan instrumen terbuka, wawancara, dan studi dokumentatif terhadap hasil-hasil kerja dosen.

Teknik pengumpulan data dilakukan melalui: 1) Observasi dan survey lapangan. 2) Wawancara terhadap mahasiswa dan dosen. 3) Analisis terhadap data sekunder terhadap dokumen yang terkait dengan pembelajaran dan pembinaan dosen muda.

Instrumen pengumpul data, ditentukan berdasarkan data yang diperlukan dari sejumlah sumber data. Ada pun instrumen yang dapat digunakan ialah: 1) Pedoman Observasi (Survey) dan Studi Dokumen. 2) Pedoman Wawancara. 3) Format-format Analisis.

\section{Temuan dan Pembahasan}

Informasi dalam bagian ini lebih terperinci kepada setiap komponen yang melekat pada kinerja dosen muda dan jenis pembinaan apa yang cocok bagi mereka, adapun temuantemuannya seperti berikut;

\section{Pengembangan Rencana, Proses dan Evaluasi Pembelajaran}

a) SAP dan Silabus yang menjadi pedoman pengajaran mata kuliah, dosen muda menjawab tidak tahu $(71,43 \%)$.

b) SAP dan Silabus mata kuliah yang disusun dosen muda berdasarkan instruksi dosen pembina (50\%)

c) Materi ajar yang disusun dosen muda merupakan hasil komparasi atas petunjuk dosen pembina dengan sumber yang dimiliki $(64,29 \%)$

d) Materi yang disusun dosen muda mengacu pada instruksi pembina $(100 \%)$

e) Sumber belajar yang digunakan dosen muda diperoleh dari dosen senior $(71,43 \%)$

f) Pengayaan terhadap sumber belajar yang dilakukan dosen muda bersumber dari internet dan sumber lainnya $(78,57 \%)$ 
g) Papan tulis dan infokus merupakan media pembelajaran yang digunakan oleh hampir seluruh dosen muda $(78,57 \%)$

h) Penguasaan dosen muda terhadap alat pendukung presentasi pembelajaran memadai untuk perkuliahan $(42,86 \%)$

i) Sebagian besar dosen muda menyatakan $100 \%$ hadir dalam proses pembelajaran $(71,43 \%)$

j) Bentuk keterlibatan dosen muda dalam pembelajaran berupa pemberian materi secara bergantian $(41,43 \%)$

k) Dalam evaluasi pembelajaran, dosen muda memperoleh kesempatan untuk mengembangkan alat evaluasi $(100 \%)$.

\section{Disiplin, Sikap, dan Hubungan Kerja}

a) Kehadiran dosen muda pada perkuliahan sesuai dengan standar minimal yang ditetapkan/disyaratkan $(71,43 \%)$

b) Kehadiran dosen muda di dalam kelas merupakan bagian dari tugas dan tanggungjawab (100\%)

c) Tugas-tugas yang diberikan dosen pembina, oleh dosen muda diselesaikan sesuai permintaan dosen pembina $(64,29 \%)$

d) Dosen muda dalam berpenampilan sesuai dengan kode etik yang berlaku $(71,43 \%)$

e) Dosen muda tidak memposisikan dosen pembina sebagai orang tua maupun kolega dalam pekerjaan, melainkan tetap memposisikannya sebagai dosen pembina $(64,29 \%)$

f) Pola hubungan yang dikembangkan oleh dosen muda terhadap dosen pembina berbentuk kolegialitas dan senioritas (masing-masing 50\%).

\section{Manajemen \&Produktivitas Kerja}

a) Sebagian besar karya ilmiah yang dihasilkan berupa buku dan jurnal $(57,14 \%)$

b) Karya ilmiah yang dihasilkan dosen muda merupakan karya ilmiah mandiri $(71,43 \%)$

c) Hasil karya ilmiah dosen muda yang terpublikasi jumlahnya berkisar di bawah 5 buah $(57,14 \%)$

d) Sebagian besar karya ilmiah yang dihasilkan masih terbatas pada lingkup institusional $(57,14)$

e) Ruang lingkup keterlibatan dosen muda dalam birokrasi masih sebatas pada lingkup universitas dan jurusan $(28,57 \%)$

f) Pelaksanaan tugas sehari-hari sesuai dengan yang tersusun dalam time scedule yang jelas $(100 \%)$

g) Keterlibatan dosen muda pada Program Studi Administrasi Pendidikan merupakan upaya dalam membentuk/membangun proses kematang diri $(71,43)$

h) Menjadi dosen pada Program Studi Administrasi Pendidikan merupakan sebuah prestasi yang dicapai $(50 \%)$

i) Dalam mengembangkan dosen muda, Program Studi Administrasi Pendidikan sudah memiliki aturan yang jelas $(57,14 \%)$.

\section{Kebijakan Ketenagaan}

a) Program pengembangan dosen dalam pembelajaran berupa sit-in pada setiap mata kuliah minat $(57,14)$

b) Dosen muda yang berhak mengajar di Prodi Administrasi Pendidikan adalah yang memiliki latar pendidikan S3 sebidang $(71,43)$

c) Evaluasi terhadap dosen muda sebaiknya dilakukan oleh mahasiswa 
$(57,14 \%)$

d) Evaluasi kinerja dosen dilakukan secara periodik pada akhir semester $(85,71 \%)$

e) Subtansi evaluasi kinerja dosen muda meliputi kehadiran dan keterampilan $(71,43 \%)$.

\section{Pandangan Mahasiswa}

a) Tingkat kehadiran dosen muda sangat baik $(42,50 \%)$

b) Penampilan dosen muda di kelas baik $(50 \%)$

c) Keterampilan dosen muda dalam mengajar di kelas baik $(67,50 \%)$

d) Keterampilan dalam penggunaan media mengajar di kelas baik $(50 \%)$

e) Penguasaan materi ajar dosen muda baik $(55 \%)$

f) Penggunaan sumber-sumber bahan ajar dosen muda baik $(37,50 \%)$

g) Penguasaan kelas dari dosen muda sangat baik $(42,50 \%)$

h) Kemampuan dosen muda dalam melakukan evaluasi baik $(42,50 \%)$

i) Kemampuan dosen muda dalam berkomunikasi di kelas baik (55\%)

j) Hubungan dosen muda degan anggota kelas sangat baik $(47,50 \%)$

k) Posisi dosen muda dengan dosen pembina dalam pembelajaran baik $(65 \%)$.

Adapun hasil wawancara dengan dosendosen senior diperoleh data seperti berikut:

a) Bagaimana menurut anda profil dosen muda pada program studi administrasi pendidikan sekarang ini?

(1) Berbicara profil dosen muda yang sekarang ada di program studi administrasi pendidikan (s2) ada kesan masih belum masuk semuanya secara keseluruhan, beberapa diantaranya masih membutuhkan bimbingan.

(2) Cerdas, terampil dalam pembelajaran, dan tentunya memiliki etika dalam hubungan kolegial

(3) Profil dosen muda kita sekarang sudah bagus, latar belakang semuanya s3, kemampuan pembelajaran baik, dan penguasaan keilmuan juga hebat

(4) Profil dosen muda ditunjukan oleh sikap profesi

(5) Profil dosen muda dilihat dari tiga aspek 1) kemampuan, 2) pengetahuan, 3) sikap

b) Apakah mereka sudah memenuhi ketentuan untuk dapat mengajar pada program studi administrasi pendidikan?

(1) Latar pendidikan sudah memenuhi, pemahaman substansi secara utuh masih perlu ditingkatkan

(2) Ketentuan kepegawaian tentunya sudah memenuhi hanya perlu dipertegas lagi mengenai ketentuan tentang hak setiap orang menjadi dosen di Prodi Adpend khususnya.

(3) Ketentuan yang menjadi standar saya kira ketika mereka dilibatkan tentunya sudah memenuhi, tidak mungkin prodi menerimanya

(4) Ketentuan yang dimaksudkan adalah standar profesi terutama dari sisi kompetensi masih beragam, adanya yang sudah tinggi dan ada yang masih harus terus dibina

(5) Ketentuan mengajar tentunya mengacu kepada aturan pada tingkat universitas dan peraturan pasca sarjana

c) Bagaimana seharusnya mereka dikembangkan dalam pekerjaannya?

(1) Polapembinaandenganpencangkokan 
melalui satu dosen pembina satu dosen muda, berdasarkan keminatan terutama bidang kedoktorannya

(2) Pengetahuan melalui pola magang dengan keterampilan kesempatan dengan evaluasi yang jelas, dan sikap kerja melalui pemahaman tentang peraturan.

(3) Pengembangan lain hal, mereka tentunya butuh, terutama dalam proses pembelajaran orang dewasa dan penguasaan keilmuan

(4) Pengembangan dalam pekerjaan bersumber dari hasil penilaian dari setiap komponen yang melekat pada dosen; penelitian, pembelajaran dan pengabdian

(5) Pengembangan dalam pekerjaan menjadi tugas prodi dengan melibatkan seluruh dosen senior sebagai pembina

d) Komponen apa saja menurut pendapat anda yang harus mereka dapatkan?

(1) Tentunya substansi sesuai dengan keminatan, keluasan dan kedalaman dalam pemahaman keilmuan, selanjutnya sikap dalam hubungan kerja.

(2) Yang paling krusial adalah dalam sikap hubungan dengan dosen senior dan dengan mahasiswa yang memang dari sisi usia tidak jauh berbeda

(3) Komponen dalam pembelajaran dan komponen sikap

(4) Yang terpenting adalah kepemilikan kompetensi

(5) Komponen yang terpenting adalah kompetensi

e) Apa yang harus dilakukan program studi terkait dengan pengembangan dosen muda?

(1) Yang paling penting ketika mereka diikutsertakan adalah komitmennya, tindak lanjut dari hasil evaluasi terjadi dan terbuka.

(2) Program kerja yang menyentuh penyiapan dan proses keterlibatan mereka dalam proses pembelajaran secara bertahap dan berkesinambungan.

(3) Prodi tentunya menyiapkan jalur yang cocok bagi semua dosen muda sesuai dengan bidang keilmuannya masing-masing.

(4) Prodi tentunya harus menyiapkan program pengembangan kompetensi dosen muda di pasca sarjana

(5) Prodi menilai dan membuat program pengembangan.

Sesuai dengan permasalahan yang ingin dipecahkan, maka dalam bagian ini pembahasan yang dilakukan dengan melihat temuan-temuan penelitian diatas seperti berikut:

\section{Kemampuan Dosen Muda dalam Proses Pembelajaran}

Kegiatan mengajar merupakan suatu proses kegiatan belajar mengajar dalam proses interaksi pendidikan antara guru sebagai pendidik dan siswa sebagai peserta didik dengan adanya hubungan interaksi keduanya sehingga adanya hubungan timbal balik. Pandangan ini sejalan dengan pendapat Moh Uzer Usman (1995:1) mengemukakan bahwa: " Proses belajar mengajar merupakan suatu proses yang mengandung serangkaian perbuatan guru dan siswa atas dasar hubungan timbal balik yang berlangsung dalam situasi edukatif untuk mencapai tujuan tertentu. Interaksi atau hubungan timbal balik antara guru dan siswa itu merupakan syarat utama bagi berlangsungnya proses belajar mengajar. .......".

Dalam penyusunan satua acara perkuliahan dan silabus perkuliahan, dosen muda belum dilibatkan secara keseluruhan baik 
perorangan maupun secara kelembagaan, terbukti bahwa mereka mengatakan tidak pernah tahu tentang penyusunan silabus dan satuan acara perkuliahan. Adapun mereka yang sudah mulai menyusun sap dan silabus tidak merupakan hasil mandiri akan tetapi masih menunggu hal-hal yang sifatnya instruksi dari dosen senior/pembina.

Bahan ajar/materi ajar dari dosen muda masih mengandalkan kepada hasil-hasil yang sudah dilakukan oleh dosen senior/ pembina, komparasi dilakukan itupun masih berdasarkan petunjuk dan sumbersumber yang dimiliki oleh dosen senior/ pembina. Dengan demikian bahwa instruksi dosen pembina masih menjadi acuan dalam penyusunan Sap, silabus, dan pengembangan materi ajar.

Sebagai pendidik, guru mengemban tugas membimbing peserta didiknya agar dapat tumbuh-kembang optimal untuk menjadi dan menemukan jati dirinya (being a good citizen) dengan berlandaskan kepada filosofi pendidikan yang berorientasi pada peserta didik (student oriented) melalui pendekatan psikologis, sosiologis dan pedagodis. Sebagai pengajar, guru mengemban tugas untuk mewujudkan suasana dan proses pembelajaran agar peserta didik dapat mengembangkan potensinya secara optimal untuk secara cerdas memiliki dan menguasai pengetahuan dan keterampilan (having skills and scientific knowledge) dengan berlandaskan filosofi pembelajaran yang mengutamakan bahan pelajaran (subject matter) dan strategi pembelajaran teknometodologik.

Bahan-bahan yang menjadi acuan sumber belajar bagi mahasiswa yang disediakan dosen muda merupakan perolehan dari dosen senior/pembina, akan tetapi dalam pengayaannya sudah menggunakan sumbersumber yang diperoleh dari jaringan internet dan sumber lainnya yang mendukung. Hal yang mendukung seperti dikatakan oleh mahasiswa bahwa ketika mereka diberikan tanggungjawab dalam menyampaikan materi maka penguasaan materi ajar dosen muda baik. Terlihat dari penguasaan dan penggunaan sumber-sumber bahan ajar oleh dosen muda baik.

Dalam penggunaan media ajar, seperti papan tulis, infocus dosen muda sudah dengan baik menggunakannya disertai dengan modelmodel presentasi yang menarik dikemas dengan menggunakan ICT yang baik. Hal ini disebabkan oleh penguasaan media presentasi pembelajaran oleh dosen muda seperti power point sudah sangat baik.

Mahasiswa sebagai pengguna jasa layanan pembelajaran dari dosen muda, walaupun tidak sepenuhnya mereka merasakan proses pembelajaran, akan tetapi mereka mengatakan bahwa dosen muda dalam keterampilan mengajar di kelas sudah baik, termasuk ketika mereka memperlihatkan keterampilan dalam penggunaan media mengajar di kelas.

Kehadiran adalah aspek yang penting dalam pembinaan dosen muda, aspek ini cukup menggembirakan karena kehadiran dalam pembelajaran sebagian besar sudah mulai konsisten. Dalam pengembangannya, kehadiran tersebut perlu didukung oleh bentuk-bentuk pelibatan mereka dalam pembelajaran, karena dalam pemberian materi belum sepenuhnya mereka dilibatkan. Begitupun dalam proses evaluasi masih sebagian diantaranya yang dilibatkan, sementara lainnya pengembangan evaluasi pembelajaran masih merupakan dominasi dosen senior/pembina. Mahasiswa melihat bahwa tingkat kehadiran dosen muda di kelas sudah sangat baik.

\section{Komitmen dan Tanggungjawab Dosen Muda Terhadap Tugas Pokok dan Fungsi}

Kehadiran adalah ukuran sebuah komitmen, adapun kehadiran dosen muda pada perkuliahan menggunakan alat ukur 
kesesuaian dengan standar minimal yang ditetapkan/disyaratkan oleh institusi. Dimana kehadiran dosen muda di dalam kelas harus merupakan bagian dari tugas dan tanggungjawabnya.

Sejalan dengan itu Smith (1982: 393), menyatakan kinerja adalah "....output drive from processes, human or otherwise”. artinya kinerja merupakan hasil atau keluaran dari suatu proses.

Dalam aspek tugas yang dibebankan oleh dosen pembina/senior, tugas-tugas yang diberikan dosen pembina, oleh dosen muda diselesaikan sesuai permintaan dosen pembina, artinya bahwa dosen muda disatu sisi sangat bergantung kepada dosen senior/ pembina disisi lain belum menampakan aspek kemandirian berupa kreativitas dan daya inovatifnya.

Penampilan dalam pembelajaran sebagai bagian dari penampilan seorang profesional, dosen muda dalam berpenampilan sesuai dengan kode etik yang berlaku sebagai aturan dalam profesi dosen di UPI. Hal ini didukung oleh jawaban dari mahasiswa bahwa penampilan dosen muda di kelas sudah baik. Penguasaan kelas dari dosen muda sangat baik, dan kemampuan dosen muda dalam melakukan evaluasi sudah baik. Selanjutnya kemampuan dosen muda dalam berkomunikasi di kelas baik, dan hubungan dosen muda degan anggota kelas sudah sangat baik.

Hubungan kerja antara dosen muda dan dosen senior, dosen muda tidak memposisikan dosen pembina sebagai orang tua maupun kolega dalam pekerjaan, melainkan tetap memposisikannya sebagai dosen pembina, dimana pola hubungan yang dikembangkan oleh dosen muda terhadap dosen pembina berbentuk kolegialitas dan senioritas. Pandangan mahasiswa memposisikan dosen muda dengan dosen pembina dalam pembelajaran sudah baik.

Kaitannya dengan hal itu, Cogan (Saiful Sagala, 2000:209) mengemukakan kompetensi guru harus mempunyai, yaitu: “a) kemampuan untuk memandang dan mendekati masalah-masalah pendidikan dari prespektif masyarakat global, b) kemampuan untuk bekerjasama dengan orang lain secara koperatif dan bertanggung jawab sesuai dengan peranan dan tugas dalam masyarakat, c) kapasitas kemampuan berfikir secara kritis dan sistematis, d) keinginan untuk selalu meningkatkan kemampuan intelektual sesuai dengan tuntutan zaman yang selalu berubah sesuai dengan perkembangan ilmu pengetahun dan teknologi.

Karya ilmiah yang dihasilkan sebagian besar karya ilmiah berupa buku dan jurnal, dan karya ilmiah yang dihasilkan dosen muda merupakan karya ilmiah mandiri dimana hasil karya ilmiah dosen muda yang terpublikasi jumlahnya berkisar dibawah 5 buah dan itupun terpublikasi masih terbatas pada lingkup institusional.

Kaitannya dengan karya ilmiah yang dihasilkan masih rendah, pendapat tentang faktor-faktor yang mempengaruhi kinerja, seperti dikemukakan Amstrong dan Baron (1998:16) yaitu sebagai berikut: (1) Personal factor, ditujukan oleh tingkat keterampilan kompetensi yang dimiliki, motivasi dan komitmen individu; (2) Leadership factor, ditentukan oleh kualitas dorongan, bimbingan, dan dukungan yang dilakukan manajer dan team leader; (3) Team factor, ditunjukan oleh kualitas dukungan yang diberikan oleh rekan kerjanya; (4) Sytem factor, ditunjukkan oleh adanya sistem kerja dan fasilitas yang diberikan organisasi; dan (5) Contextual/ situational factors, ditunjukkan oleh tingginya tingkat tekanan dan perubahan lingkungan internal dan eksternal.

Ruang lingkup keterlibatan dosen muda dalam birokrasi masih sebatas pada lingkup universitas dan jurusan, dimana dalam pelaksanaan tugas sehari-hari sesuai dengan yang tersusun dalam time scedule yang jelas. Keterlibatan dosen muda pada Program Studi Administrasi Pendidikan merupakan upaya dalam membentuk/membangun proses kematangan diri, dimana menjadi dosen pada Program Studi Administrasi Pendidikan 
merupakan sebuah prestasi yang dicapai.

\section{Pola-Pola Kaderisasi Dilakukan Dalam Pengembangan Dosen Muda}

Penting untuk dikemukakan bahwa dosen muda yang berhak mengajar di Prodi Administrasi Pendidikan adalah yang memiliki latar pendidikan S3 sebidang, dimana profil dosen muda yang sekarang ada di program studi administrasi pendidikan (s2) ada kesan masih belum masuk semuanya secara keseluruhan, beberapa diantaranya masih membutuhkan bimbingan. Hal pokok yang dibutuhkan meliputi cerdas, terampil dalam pembelajaran, dan tentunya memiliki etika dalam hubungan kolegial.

Didukung juga oleh data selanjutnya dimana profil dosen muda kita sekarang sudah bagus, latar belakang semuanya s3, kemampuan pembelajaran baik, dan penguasaan keilmuan juga hebat, profil dosen muda ditunjukan oleh sikap profesi dan profil dosen muda tersebut harus dilihat dari tiga aspek 1) kemampuan, 2) pengetahuan, 3) sikap.

Latar pendidikan menjadi hal yang sangat penting, karena akan berkaitan dengan pemahaman substansi yang secara utuh masih harus perlu ditingkatkan. Sejalan dengan ketentuan kepegawaian tentunya sudah memenuhi hanya perlu dipertegas lagi mengenai ketentuan tentang hak setiap orang menjadi dosen di Prodi Adpend khususnya. Ketentuan yang menjadi standar ketika mereka dilibatkan mengikuti aturan yand ada dan tidak mungkin prodi menerimanya. Ketentuan yang dimaksudkan adalah standar profesi terutama dari sisi kompetensi masih beragam, adanya yang sudah tinggi dan ada yang masih harus terus dibina. Dalam pengajaran, ketentuan tentang hak mengajar tentunya mengacu kepada aturan pada tingkat universitas dan peraturan pasca sarjana.

Program pengembangan dosen dalam pembelajaran berupa sit-in pada setiap mata kuliah minat. Pola pembinaan dengan pencangkokan melalui satu dosen pembina satu dosen muda, dipertimbangkan berdasarkan keminatan terutama bidang kedoktorannya. Dengan kegiatan seperti tersebut akan membangun pengetahuan melalui pola magang dengan keterampilan kesempatan dengan evaluasi yang jelas, dan sikap kerja melalui pemahaman tentang peraturan. Pengembangan hal lainnya yang mereka butuhkan, terutama dalam proses pembelajaran orang dewasa dan penguasaan keilmuan.

Untuk memberikan keseimbangan dalam penugasan dan peraturan perlu juga dilibatkan mahasiswa secara adil dalam penilaian, evaluasi terhadap dosen muda sebaiknya dilakukan oleh mahasiswa, dimana evaluasi kinerja dosen dilakukan secara periodik pada akhir semester dan subtansi evaluasi kinerja dosen muda meliputi kehadiran dan keterampilannya.

Penting ketika mereka diikutsertakan adalah komitmennya, tindak lanjut dari hasil evaluasi terjadi dan terbuka. Selanjutnya dalam pengembangan kebijakan pengembangan dosen muda tentunya program kerja yang menyentuh penyiapan dan proses keterlibatan mereka dalam proses pembelajaran secara bertahap dan berkesinambungan. Prodi tentunya menyiapkan jalur yang cocok bagi semua dosen muda sesuai dengan bidang keilmuannya masing-masing. Prodi harus menyiapkan program pengembangan kompetensi dosen muda di pasca sarjana, dan prodi menilai dan membuat program pengembangan.

\section{Pengembangan Model}

\section{Kerangka Model Pembinaan Dosen Muda}

\section{Deskripsi Model Pembinaan Dosen Muda}

Pembinaan dan pengembangan dosen muda di Program Studi Administrasi Pendidikan bersumber dari Peraturan Pengelolaan Sumber Daya Manusia di UPI, pada proses rekruitmen tentunya Program Studi 


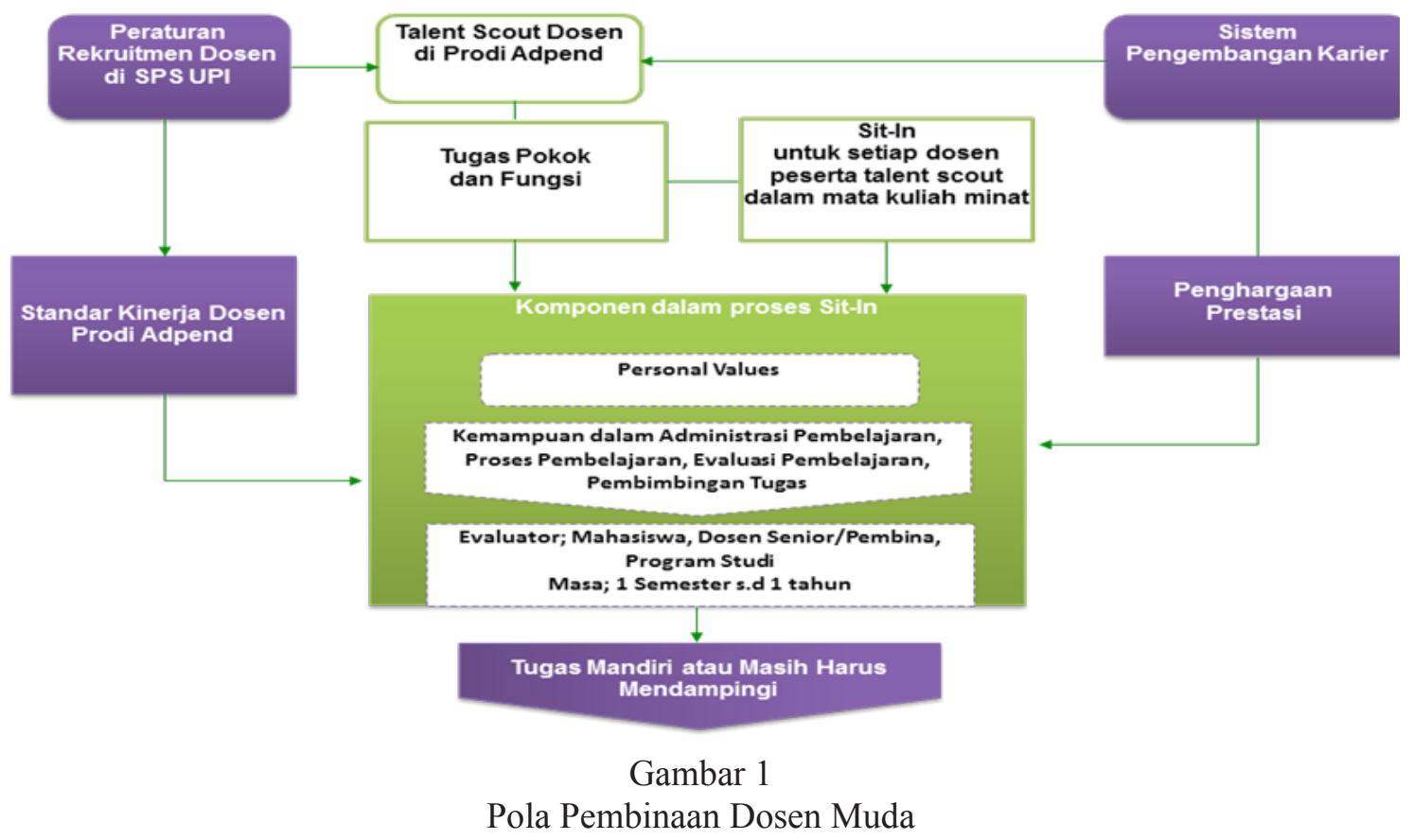

Administrasi Pendidikan memperhatikan peraturan tersebut, dimana dalam pelaksanaan rekruitmen tenaga pengajar di pasca sarjana dimungkinkan untuk "open resourcess". Perlu dipertimbangkan bahwa rekruitmen dosen untuk tenaga pengajar pada Program Studi Administrasi Pendidikan pada tingkat S2 dan S3 pemilikan tenaga-tenaga dosen yang ada pada jenjang $\mathrm{S} 1$.

Melalui proses pemberdayaan tenaga dosen pada tingkat $\mathrm{S} 1$, dengan pemenuhan persyaratannya memungkinkan memberikan peluang yang terbuka dalam pengembangan kariernya, terutama dalam proses penyiapan guru besar. Selanjutnya untuk kepentingan mutu tentunya selain persyaratan karena latar belakang pendidikan yang memenuhi dan sebagai tenaga pengajar pada jenjang S1 Jurusan Administrasi Pendidikan, tetap harus menjadi acuan yaitu standar kinerja. Standar kinerja akan menjadi acuan dalam proses akselarasi dosen muda menjadi dosen pembina mata kuliah. Selain itu standar kinerja juga menjadi acuan bagi bentukbentuk penghargaan yang diberikan oleh SPS.

Model pembinaan yang dikembangkan, untuk bisa mengakomodasi pemikiranpemikiran diatas harus meliputi sebuah proses pelibatan dosen S1 dengan standar kinerja yang ditentukan dan pembinaan dalam hal pengembangan karier pegawai. Kearah pembinaan yang efektif dengan hasil dosen muda yang berkualitas, perlu diawali dengan kegiatan yang mampu mesosialisasikan tugas pokok dan fungsi keterlibatan dosen muda dalam struktur pasca sarjana, bila tidak terjadi pola-pola hubungan andragogi dan tidak berlangsung dengan baik akan memposisikan mental akademik tidak berimbang dengan "power mentalism". Dimana ego karena mengajar untuk orang-orang tertentu dengan atributnya akan mengalahkan kematangan akademiknya.

Proses pelibatan dalam pembelajaran meliputi proses yang terus menerus dan berkesinambungan dengan target-target antara yang jelas. Komponen pertama dalam program sit-in yang harus menjadi target adalah personal values-nya, peningkatan dan pengembangan nilai-nilai personal yang bersumber dari nilai-nilai organisasi. Komponen kedua, adalah komponen teknis dalam pembelajaran; pengenalan 
administrasi kelas pada tingkat pasca, pengelolaan kelas, rencana pembelajaran, sampai pada kesempatan untuk mengimplementasikan rencana tersebut dan kemudian mengevaluasinya.

Untuk kepentingan keberhasilan mengikuti proses, komponen mahasiswa, dosen senior, dan ketua program studi menjadi evaluator. Masa evaluasi meliputi satu semester berjalan sampai dengan satu tahun. Hasilnya akan mereposisi dosen muda untuk bisa mandiri mengajar atau masih harus mendampingi dosen senior/pembina.

\section{Komponen Model Pembinaan Dosen Muda}

Komponen-komponen dalam model pembinaan dosen muda ini meliputi hal-hal berikut; (a) Kebijakan Integrasi, komponen yang pertama perlu ada dalam proses pembinaan dosen muda adalah kebijakan tentang integrasi kurikulum antara S1,S2, dan S3 bahkan sampai kepada kebijakan pengelolaannya. Hal ini harus ada supaya terjadi sinergi dalam pengelolaan ketenagaan yang memposisikan bidang kepakaran masing-masing dosen; (b) Program Kerja Program Studi, program kerja pada tingkat program studi tentunya harus menyentuh sisi ini karena kepentingan dalam pengembangan harus jelas tujuan yang ingin dicapai, proses yang berlangsung seperti apa, dan aturanaturan internal program studi yang tegas dengan komposisi pembiayaan yang adil dan jujur; (c) Iklim Organisasi, butuh sebuah iklim yang harmonis dalam pembinaan dosen muda, ada rasa adil, kesempatan yang sama, politik yang tidak berlebihan, komitmen organisasi yang tinggi; dan (d) Sumber Daya Manusia, pembinaan dosen muda bersumber dari adanya dosennya itu sendiri, aktualisasi diri dalam berbagai kegiatan kadang mengalhkan keinginan untuk memperlihatkan semangat mengabdi dan membangun institusi. Kerap kehilangan dosen muda dengan berbagai alasan aktualisasi diri di luar institusi.

\section{Tujuan Model Pembinaan Dosen Muda}

Tujuan dari model pembinaan dosen muda yang ingin dicapai, sebagai berikut; (a) Pengembangan karier dosen muda, pembinaan dosen muda tidak semata-mata melibatkan dosen muda dalam sebuah proses dan struktur pembelajaran pada tingkat strata 2 atau 3, akan tetapi perlu dilihat jangka panjang ada makna yang lebih tinggi. Karier dalam institusi UPI harus menjadi panduan dalam pengembangan dosen muda, sehingga pembinaan dan pengembangan karier bisa berjalan dengan baik; (b) Peningkatan kinerja dosen, pembinaan dosen semata-mata tidak hanya mempersiapkan adanya generasi penerus, akan tetapi juga bagaimana dapat terjaganya kinerja dosen; (c) Penyiapan dan akselerasi guru besar, hal penting dalam menjaga institusi terutama di perguruan tinggi, dalam hal ini program studi administrasi pendidikan adalah adanya orang-orang yang pakar dengan tingkat prestasi akademik sebagai guru besar. Karena bila terjadi kemandegan dalam penyiapan guru besar bukan tidak mungkin terjadi pencabutan ijin operasi program studi dan ini juga kerugian bagi UPI; dan (d) Peningkatan Mutu Layanan, peningkatan mutu layanan akademik adalah target yang penting dalam pembinaan dosen muda. Komponen-komponen mutu pembelajaran dapat diteruskan dari dosen senior/pembina kepada dosen muda.

\section{Metode Pengawasan}

a) Metode Langsung (Directive Methods)

Pendekatan terhadap masalah yang bersifat langsung. Dosen senior memberikan arahan langsung. Sudah tentu pengaruh perilaku Dosen Senior lebih dominan. Pendekatan direktif ini berdasarkan pemahaman terhadap psikologi behaviorisme. Prinsip behaviorisme ialah bahwa segala perbuatan berasal dari refleks, yaitu respons terhadap rangsangan/ stimulus. Oleh karena guru 
ini mengalami kekurangan, maka perlu diberikan rangsangan agar is bisa bereaksi. Dosen senior atau Ketua Program Studi dapat menggunakan penguatan (reinforcement) atau hukuman (punishment). metode seperti ini dapat dilakukan dengan perilaku pengawas seperti berikut: 1) menjelaskan, 2) menyajikan, 3) mengarahkan, 4) memberi contoh, 5) menetapkan tolok ukur, 6) menguatkan.

\section{Metode Tidak Langsung (Non-Direktif Methods)}

Pendekatan tidak langsung (non-direktif) adalah cara pendekatan terhadappermasalahan yang sifatnya tidak langsung. Perilaku dosen senior atau letua program studi tidak secara langsung menunjukkan permasalahan, tapi ia terlebih dulu mendengarkan secara aktif apa yang dikemukakan dosen muda. Ia memberi kesempatan sebanyak mungkin kepada dosen muda untuk mengemukakan permasalahan yang mereka alami. Pendekatan non-direktif ini berdasarkan pemahaman psikologis humanistik. Psikologi humanistik sangat menghargai orang yang akan dibantu. Oleh karena pribadi dosen muda yang dibina begitu dihormati, maka ia lebih banyak mendengarkan permasalahan yang dihadapi dosen muda dalam menjalankan tugasnya. Dosen muda mengemukakan masalahnya. Dosen senior atau ketua program studi mencoba mendengarkan, memahami apa yang dialami dosen muda. Perilaku dosen senior atau ketua program studi dalam pendekatan non-direktif adalah sebagai berikut: 1) mendengarkan, 2) memberi penguatan, 3) menjelaskan, 4) menyajikan, dan 5) memecahkan masalah.

b) Pendekatan Kolaboratif

Pendekatan kolaboratif adalah cara pendekatan yang memadukan cara pendekatan direktif dan nondirektif menjadi cara pendekatan baru. Pada pendekatan ini baik Dosen Senior atau Ketua Jurusan maupun dosen muda bersama-sama, bersepakat untuk menetapkan struktur, proses dan kriteria dalam melaksanakan proses percakapan terhadap masalah yang dihadapi guru. Pendekatan ini didasarkan pada psikologi kognitif. Psikologi kognitif beranggapan bahwa belajar adalah hasil paduan antara kegiatan individu dengan lingkungan pada gilirannya nanti berpengaruh dalam pembentukan aktivitas individu. Dengan demikian pendekatan dalam supervisi berhubungan pada dua arah. Dari atas ke bawah dan dari bawah ke atas. Perilaku Dosen senior atau Ketua Program Studi adalah sebagai berikut: 1) menyajikan, 2) menjelaskan, 3) mendengarkan, 4) memecahkan masalah, 5) negosiasi.

\section{Indikator Keberhasilan Pembinaan Dosen Muda}

Indikator keberhasilan model pembinaan dosen muda meliputi hal-hal seperti berikut: (a) Terjaganya akselerasi dalam menghasilkan guru besar setiap tahunnya; (b) Terbinanya setiap mata kuliah dengan baik, baik dari sisi isi ataupun perkembangan ilmu pengetahuan dan teknologi; (c) Terintegrasinya pengelolaan kurikulum maupun manajemen pada tingkat S1, S2, dan S3; (d) Meningkatnya kinerja dosen baik dosen muda maupun dosen senior/Pembina; dan (e) Meratanya kesejahteraan dosen.

\section{KESIMPULAN}

Mengukur kinerja dosen yang baik harus dilakukan dengan melihat pencapaian setiap komponen dalam indikator akademik, penelitian dan pengabdian kepada masyarakat. Pemahaman dan kemampuan dosen muda dalam menerjemahkan tugas dan tanggungjawabnya menjadi ukuran dosen muda dapat memperoleh kesempatan madiri dalam pembelajaran atau masih harus memperoleh bimbingan dari dosen senior/ pembina.

Dalam kerangka dosen di UPI, dosen muda di Program Studi Administrasi Pendidikan harus mampu memenuhi ketiga indikator tersebut, dimana ketiganya menjadi satu kesatuan 
tanggungjawab yang tidak bisa dilepaskan pemenuhannya harus menyeluruh. Dalam bidang akademik dibuktikan dengan proses pembelajaran dan bimbingan yang dilakukan di kelas, penelitian dibuktikan dengan karya ilmiah yang dihasilan, dan pengabdian masyarakat dibuktikan dengan bentukbentuk pengembangan yang bermanfaat bagi kehidupan masyarakat, baik masyarakat umum maupun secara khusus masyarakat pendidikan.

Kemampuan dosen muda dalam pembelajaran berdasarkan hasil penelitian dikatakan sudah baik, bahwa proses penyiapan satuan acara perkuliahan dan silabus mereka sudah terlibat walaupun masih sebatas meneruskan sap dan silabus yang sudah disiapkan oleh dosen senior/pembina, dari sisi sikap dan hubungan dengan dosen senior/pembina dikatakan masih ada sedikit kekurangan kemungkinan penyebab yang ditemukan berkaitan dengan posisi mereka dengan status doktor berbanding dengan kematangan sikapnya.

Penampilan dalam pembelajaran sebagai bagian dari penampilan seorang profesional, dosen muda dalam berpenampilan sesuai dengan kode etik yang berlaku sebagai aturan dalam profesi dosen di UPI. Hubungan kerja antara dosen muda dan dosen senior, dosen muda tidak memposisikan dosen pembina sebagai orang tua maupun kolega dalam pekerjaan, melainkan tetap memposisikannya sebagai dosen pembina, dimana pola hubungan yang dikembangkan oleh dosen muda terhadap dosen pembina berbentuk kolegialitas dan senioritas. Pandangan mahasiswa memposisikan dosen muda dengan dosen pembina dalam pembelajaran sudah baik. Walaupun masih ada kasus yang memposisikan dosen muda kurang bagus, seperti kehadiran, ada diantaranya masih mengabaikan aspek ini terutama ketika kaitannya dalam hubungan pembinaan yang dilakukan oleh dosen senior/pembina.

Dari hasil penelitian yang ditemukan dalam pengembangan dosen muda pada Program
Studi Administrasi Pendidikan SPS UPI, disarankan hal-hal berikut:

\section{Program Studi}

Secara kelembagaan program pengembangan dosen muda di Program Studi Administrasi Pendidikan sudah terlihat, akan tetapi perlu diredesain lagi berkaitan dengan; (a) Model Pengembangan dosen muda, model yang disiapkan dapat dikembangkan dan disosialisasikan dengan baik sehingga dosen pembina/senior dan dosen muda memiliki arah yang jelas dan keamanan dalam pengembangan profesinya, terutama berkaitan dengan penyiapan guru besar; (b) Program Penyiapan, program penyiapan dosen muda disusun secara sistematis dengan target-target yang jelas sehingga secara administratif dapat dipertanggungjawabkan. (c) Kebijakan yang adil dalam pelibatan, kebijakan pengembangan melalui aktivitasaktivitas pelibatan dosen muda dalam program jurusan mengedepankan rasa adil dan jujur; dan (d) Penghargaan atas tugas dirasakan oleh semua sebagai sebuah motivasi yang mendorong untuk meningkatkan kapabilitas dan kapasitas dalam bekerja semakin baik.

- Beberapa hal yang wajib dilaksanakan yaitu: (a) Wajib mendapat pembinaan, sebelum memegang mata kuliah secara mandiri; (b) Pembinaan dosen muda (asisten ahli) dilakukan melalui penelitian bersama dan tim pengajaran; (c) Tidak dibolehkan menentukan penilaian akhir hasil evaluasi belajar mahasiswa; (d) Proporsi dosen muda dalam tim pengajaran harus lebih kecil dari pada dosen pembinanya; dan (e) Dosen pembina harus dapat mengarahkan dosen muda untuk studi lanjut pada bidang ilmu yang digeluti bersama.

- Penindakan terhadap pelanggar disiplin akademik: (a) Dosen tidak aktif mengajar adalah dosen yang meninggalkan prodi tanpa izin sehingga tidak dapat menjalankan tugas mengajarnya; (b) 
Ketua Program Studi segera melakukan peringatan dan pemanggilan terhadap dosen secara langsung; dan (c) Apabila tidak ada respon, maka program studi harus segera melaporkan kepada Pasca Sarjana untuk meminta penindakan lanjut

\section{Dosen Muda}

Dosen muda sebagai penerus, tentunya ada hal-hal yang harus dimiliki, seperti berikut; (a) Sikap mental, bahwa proses itu membutuhkan waktu dimana pengakuan muncul dari proses "action", oleh karenannya keseimbangan sikap mental dan pencapaian gelar akademik harus semakin diimbangkan. (b) Kompetensi, latar pendidikan sering menjadi kendala dalam pengembangan. Dibutuhkan upaya yang keras melalui proses belajar yang terus menerus dalam bidang akademik, pedagogik, pribadi dan sosial; (c) Komitmen, ukuran kesamaan antara dosen muda dan dosen senior hanya disatu titik yaitu komitmen; (d) Pengembangan Karakter Diri, karakter diri sering menjadi masalah bahwa peraturan itu adalah petunjuk jalan dan kesadaran (self awareness) ukuran sebenarnya keberhasilan dalam pembelajaran.

\section{Dosen Senior Pembina}

a) Kesempatan, selain kesesuain dengan aturan yang ada dibutuhkan pemberian kesempatan untuk memperoleh kepercayaan diri dan kemandirian dari dosen muda.

b) Perimbangan peran, perimbangan peran antara pembina dalam karier kepegawaian dosen muda dan orang tua.

\section{DAFTAR PUSTAKA}

Bates, R., \& Holton, E. F. III (1995). Computerized work performance monitoring: A review of human resource issues. Human Resource Management Review.

Brown, L., LaFond A., Macintyre, K. (2001), Measuring Capacity. Building, Carolina Population Centre/University of North Carolina.

Mitchel, T.R. (1978). People in Organization Understanding Their Behaviour. Tokyo: Mac Graw Hill

Nanang F. (1999), Landasan Manajemen Pendidikan. Bandung: Remaja Rosdakarya

Senge, P.M. and Carstedt, G.(2002). "Innovating Our Way to the Next Industrial Revolution.” In Marius Leibold, Gilbert Probst and Michael Gibbert, Strategic Management in the Knowledge Economy. J.Wiley.

Senge, P.M., (1996), "Leading Learning Organizations: The Bold, the Powerful, \& the Invisible.” In M. Goldsmith and F. Hasselbein (eds.), The Leader of the Future. San Francisco, CA: Jossey-Bass Inc.

Santrock, W. J. 2004. Educational Psychology: 2nd Edition. McGraw-Hill Company, inc.

Sagala, S. (2009). Kemampuan Profesional Guru \& Tenaga Kependidikan. Bandung: Alfabeta.

Uzer, U. M. (2001). Menjadi Guru Profesional. Bandung: Rosdakarya.

Undang-Undang Sistem Pendidikan Nasional No. 20 tahun 2003, tentang Sistem Pendidikan Nasional.

Undang-Undang Guru dan Dosen No. 14 tahun 2005, tentang Guru dan Dosen. 